\title{
Historical and Scientific Investigations into the Use of Hydraulic Lime in Korea and Preventive Conservation of Historic Masonry Structures
}

\author{
Sung-Hoon Kang ${ }^{1}{ }^{\circledR}$, Sang-Ok Lee ${ }^{2, *}$, Sung-Gul Hong ${ }^{1}$ and Yang-Hee Kwon ${ }^{3, *}$ \\ 1 Department of Architecture and Architectural Engineering, Seoul National University, 1 Gwanak-ro, \\ Gwanak-gu, Seoul 08826, Korea; medesis@snu.ac.kr (S.-H.K.); sglhong@snu.ac.kr (S.-G.H.) \\ 2 Department of Conservation Science, Korea National University of Cultural Heritage, 367 Baekjemun-ro, \\ Gyuam-myeon, Buyeo-gun, Chungcheongnam-do 33115, Korea \\ 3 Department of Traditional Architecture, Korea National University of Cultural Heritage, 367 Baekjemun-ro, \\ Gyuam-myeon, Buyeo-gun, Chungcheongnam-do 33115, Korea \\ * Correspondence: 1so8675@naver.com (S.-O.L.); yanga1126@nuch.ac.kr (Y.-H.K.); Tel.: +82-41-830-7368 \\ (S.-O.L.); +82-41-830-7331 (Y.-H.K.)
}

Received: 20 August 2019; Accepted: 17 September 2019; Published: 20 September 2019

\begin{abstract}
In addition to non-hydraulic lime, natural hydraulic lime (NHL) is a material widely used to repair and restore historic buildings. In Korea, although lime mortars have been used as important building materials for thousands of years, the sharing of information and technology with other countries has been relatively inactive. While not recognizing the suitability of NHL as a repair material, undesirable materials such as Portland cement have often been selected due to their high strength, ease of use, and hydraulicity, but unfortunately, this has resulted in the irreversible damage of existing elements, especially in historic masonry structures. This study aims to emphasize the need for hydraulic lime for the sustainable preservation of Korea's architectural heritage. To justify its use, historical and scientific investigations were conducted. By reviewing literature written in the 15th century, it was found that dark limestone was used to manufacture building lime. Based on this, the chemical compositions of different-colored limestone were experimentally analyzed, and significant evidence was found that dicalcium silicate was formed in the quicklime manufactured by calcining blue-green and green-black limestone. Prior to the 19th century, it would have been impossible to record the chemical compositions of various types of limestone, except for visual observations such as color differences. Fortunately, this important information was recorded in royal documents and has been handed down to the present day. Thus, knowledge from 500 years ago could be scientifically interpreted using the latest technology. The link between the historical record and the experimental results shown in this study can contribute to the selection of a suitable material. This is a method for the preventive preservation of historic masonry structures, as it can significantly lower the possibility of future damages caused by efflorescence and freeze-thaw.
\end{abstract}

Keywords: architectural heritage; sustainable preservation; preventive conservation; historic masonry structures; limestone; hydraulic lime; natural hydraulic lime; hydraulicity; dicalcium silicate

\section{Introduction}

\subsection{Importance of Lime-Based Materials in the Preservation of Korean Architectural Heritage}

Lime-based materials are important historic building materials that have contributed significantly to the development of human culture and civilization [1,2]. They have been used to construct historic buildings and infrastructure for over 10,000 years [3]. The most advanced form, Portland cement, has 
led to the construction and expansion of cities in a short period of time, in which the hydraulicity of this binder as well as its high strength and fast strength development are involved. Hydraulicity is defined as the property of a dry powder that can harden in water or when mixed with water $[4,5]$. In Korea, lime mortars were also used for at least 1500 years as important building materials, until the early 20th century. Especially during the Joseon Dynasty (1392-1910), it was actively used due to the significant development of manufacturing technology. Many of the wooden buildings and masonry structures built during this period remain standing to date. To preserve them for hundreds or thousands of years, traditional building materials, such as lime mortar, should be continuously used.

To date, it is known that Korean traditional lime does not have hydraulic properties; hence, it can be defined as air lime, which hardens by the carbonation reaction between calcium hydroxide $\left(\mathrm{Ca}(\mathrm{OH})_{2}\right)$ and atmospheric carbon dioxide $\left(\mathrm{CO}_{2}\right)$ while forming calcium carbonate $\left(\mathrm{CaCO}_{3}\right)$ [6]. This non-hydraulic binder consists mostly of $\mathrm{Ca}(\mathrm{OH})_{2}$ and is manufactured by slaking the quicklime after burning high quality limestone, which has almost no impurities. Typically, air lime mortars containing straw and various natural additives are used as repair and restoration materials for historic buildings. Therefore, in principle, Korea's architectural heritage should be repaired using such non-hydraulic materials. However, the reality is different. Since the early 20th century, many historic buildings have been repaired using strong hydraulic materials, i.e., Portland cement. Lack of knowledge about traditional materials and techniques as well as practitioners' or workers' misunderstanding of traditional materials and the practice of using hydraulic binders have all resulted in this situation, i.e., the widespread use of inappropriate materials.

In general, choosing Portland cement as a repair material for historical buildings is regarded as undesirable in terms of the long-term economic feasibility, sustainability, and authenticity of a culture's architectural heritage [7]. Although construction periods and costs can be reduced initially, irreversible deterioration in old elements and structures can be caused by incompatibilities in strength, stiffness, and the coefficient of thermal expansion [8]. Moreover, because of its low air permeability, the cement's durability can be even lower than that of lime-based materials [9]. More seriously, efflorescence can form due to the precipitation of soluble salts, such as calcium sulfate and sodium salt, which may reduce the aesthetic value of cultural properties [10]. A good example is the recently finished (April 2019) restoration project of the Mireuksaji Stone Pagoda (located in the Baekje Historic Areas and listed as a UNESCO World Heritage Site in 2015). In this project, which took an enormous amount of time ( 20 years) and resulted in high costs ( 18,600,000 USD in 2019), one of the most demanding tasks was to manually remove 185 tons of cement mortars that were covered about 100 years ago. Hammers, chisels, and even dental tools were used to minimize the damage to the 1400-year-old stone elements.

In Korea, one of the most demanding historical structures to be repaired using traditional materials is the masonry walls of historical fortresses, such as the $12.4 \mathrm{~km}$ of walls in Namhansanseong (built in 1624 and listed as a UNESCO World Heritage Site in 2014) and the $5.7 \mathrm{~km}$ of walls in Suwon Hwaseong (built in 1796 and listed as a UNESCO World Heritage Site in 1997). In particular, in the case of Namhansanseong, since the walls consist of a thick lime mortar layer $(\sim 65 \mathrm{~mm})$, a large amount of repair material should be consumed consistently. In addition, since it was built on a mountain ridge, its preservation depends only on a non-hydraulic binder, which is practically difficult. Due to these limitations, white cement has been used, as shown in Figure 1. However, unlike the main section of the fortress, which has been steadily restored and repaired since 1970 (see the left side of Figure 1), many old sections still remain in the outer part of the fortress (see the right side of Figure 1). Because the two parts are aesthetically incongruous, one can even question the suitability of the materials and methods used for the repair and restoration. 


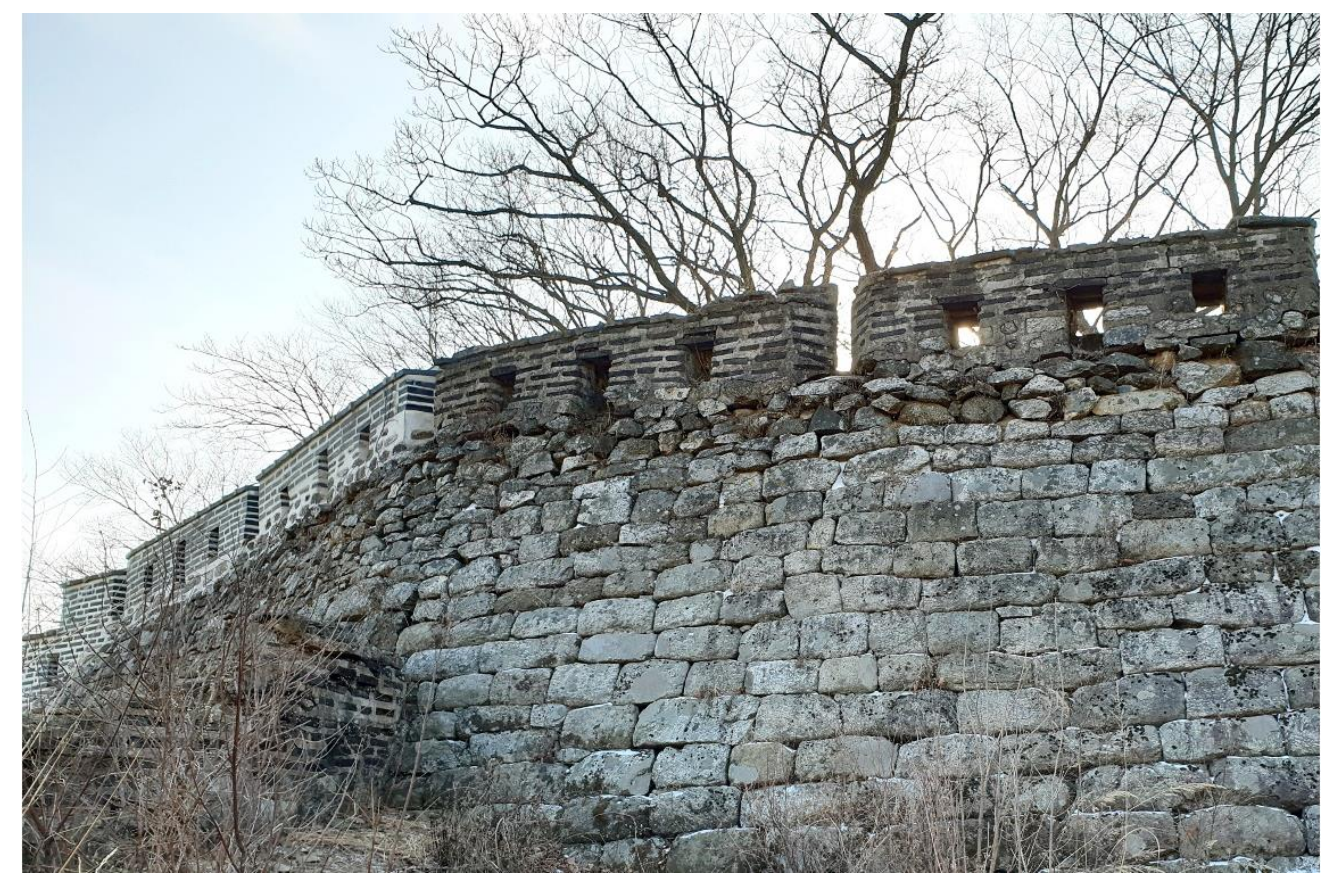

Figure 1. Fortress walls in Namhansanseong (photo taken in January 2019 by the authors).

\subsection{Preventive Conservation Strategy for Historic Masonry Structures}

Preventive conservation includes all indirect actions to increase the life of a cultural heritage, and its main purpose is to mitigate imperceptible deterioration or damage. A typical approach is to minimize the environmental impact on the heritage by optimizing light, temperature, relative humidity, and indoor air quality. In this context, many studies have focused on the indoor environment of historic buildings, such as museums [11,12] and libraries [13-15]. Lucchi [16] summarized this type of study on museum buildings conducted over 50 years, starting in 1965. In recent years, this concept has been extensively applied to various cultural heritages, such as mural paintings [17] and earthen defensive heritages [18].

In outdoor exposed historic masonry structures, such as stone pagodas and fortress walls, it is virtually impossible to actively control the environmental factors. Therefore, strategies for preventive conservation need to be adjusted, taking into consideration the characteristics of the architectural heritage. The repair and restoration of these structures are inevitable. Thus, the selection of suitable materials is closely related to the concept of preventive conservation. In historic masonry structures, salt-related deterioration, such as efflorescence, is frequent but catastrophic, and even the surfaces of structures can be damaged during their removal. As mentioned, the use of Portland cement can be responsible for this problem. Moreover, a low air permeability in the cement can accelerate the freeze-thaw damage.

In the project performed to examine the physical, chemical, and biological deterioration of masonry walls in Namhansanseong, the most frequent and severe damage was the delamination of repaired mortar caused by freeze-thaw [19]. Efflorescence was also observed in parts recently repaired using the cement. Moreover, the moisture content of newly repaired parts was higher than that of old ones. Therefore, it was concluded that the amount of moisture absorbed by mortar or bricks can significantly influence damages, such as freeze-thaw and efflorescence. Efflorescence has also been frequently observed in the heritages of the Mireuksaji Stone Pagoda and Suwon Hwaseong [20]. To remove it, physical or chemical cleaning is inevitable. However, they are only a temporary solution. Thus, this gradual and repetitive problem should be fundamentally prevented.

A high-strength mortar is generally dense and has low air permeability, hence the difficulty in drying its internal moisture [21]. Therefore, hydraulic materials with high permeability, such as 
NHL, are more suitable for use in a preventive preservation strategy. In addition, lime-based materials are considered philosophically and technically suitable in the field of historic building conservation, compared to Portland cement [22]. Moreover, these materials are eco-friendly due to their low energy consumption and greenhouse gas emissions in the manufacturing process $[6,23]$. In addition to long-term cost competitiveness, these environmental aspects are also important in preventive conservation.

\subsection{Suitability of Natural Hydraulic Lime as a Repair Material for Historic Buildings}

The use of air lime mortar has been avoided in South Korea except for strictly supervised architectural heritage sites, such as national treasures, mainly due to its low strength, slow hardening, and high risk of cracking. This non-hydraulic material hardens for more than six months while absorbing atmospheric $\mathrm{CO}_{2}$, not water, and thus it is ineffective at resisting water, especially during the initial curing period (roughly $<1$ month). Moreover, its ultimate strength is lower than $3 \mathrm{MPa}$, which is less than $10 \%$ of Portland cement-based materials [24]. For these reasons, there is a risk that large parts of the repaired structures will be lost due to environmental factors such as rain and wind [25]. In addition, modern customs common in the use of cement can lead to severe deterioration in the structural safety of old structures repaired with completely different materials, i.e., air lime mortars. One example to support this is that many practitioners and workers believe that long-term sealed curing for air lime mortar is beneficial for developing its strength. This misunderstanding might be caused by the practices involved in using hydraulic materials, and it demonstrates a lack of knowledge that the setting and hardening of air lime is possible only when drying and $\mathrm{CO}_{2}$ absorption occur [6]. This eventually leads to frequent defects and disputes, making the choice of cement-based materials inevitable. Therefore, it is important to understand the importance of hydraulic binders along with the scientific research on traditional building materials for the sustainable preservation of architectural heritage.

Unlike air lime, hydraulic lime can set and harden in a short period of time ( $<1$ month), and thus it has good usability as a repair material. In particular, NHL, which is produced by burning low-quality limestone containing impurities such as silica $\left(\mathrm{SiO}_{2}\right)$ and alumina $\left(\mathrm{Al}_{2} \mathrm{O}_{3}\right)$, contains calcium silicate as well as $\mathrm{Ca}(\mathrm{OH})_{2}$. Thus, it combines both air hardening characteristics and hydraulicity. This means that it hardens through the hydration reaction, and its strength is steadily increased by the carbonation reaction. In addition, NHL is more compatible with old materials than Portland cement because it has high air permeability as well as adequate strength and stiffness. Since it combines hydraulicity and air hardening, a target strength and durability can be guaranteed, with less sensitivity than air lime to environmental factors [26]. Compared to air lime mortar, NHL mortar shows superior mechanical properties, regardless of the type or content of the aggregates [27]. This has been demonstrated in old historic buildings; while non-hydraulic lime mortars showed 0.5-2.5 MPa of strength in Pišece Castle (Slovenia, 13th century), hydraulic lime mortars showed 8-10 MPa in Gediminas Castle Hill (Lithuania, 13-14th century) and 11-15 MPa in Alhambra Palace (Spain, 13th century) [28,29]. Furthermore, because of recent efforts to reduce greenhouse gases in the field of construction materials [23], NHL is recommended for use as a cementing material more actively in new buildings as well as old ones. In addition to its carbon capture capacity, lime has an excellent self-healing ability (the ability to fill in cracks by forming $\mathrm{CaCO}_{3}$ ). Therefore, $\mathrm{NHL}$ has been regarded as the most suitable material for the sustainable preservation of historical buildings, even when environmental sustainability is considered $[3,8,30]$.

To correctly preserve architectural heritage, it is imperative to realize the building conservation philosophy and fully understand the characteristics of the raw materials [31]. Lime-based materials, whether hydraulic or non-hydraulic, have been consistently studied over the last 40 years, mainly focusing on the characteristics of their chemical reactions in hardening as well as their various engineering properties [2]. However, the chemical composition and reactivity of quicklime and hydrated lime manufactured using limestone of various colors are insufficiently understood. In this 
context, the main purpose of this study is to scientifically analyze lime-based materials made of different-colored limestones, referring to old literature. Another important purpose is to find evidence of their hydraulicity. Additionally, the effects of the impurities on the chemical compositions of quicklime or hydrated lime were also investigated. To this end, first, literature written in the 15th century on the manufacture and use of lime mortars was reviewed. Then, limestone of various colors was analyzed using an X-ray fluorescence (XRF) technique to identify the type and content of the impurities included. Isothermal calorimetry was also conducted to quantitatively investigate the effect of impurities on the exothermic reactions occurring during lime slaking. Finally, evidence of hydraulic binders, such as the formation of calcium silicate, was collected by chemical analysis using X-ray diffraction (XRD) and thermogravimetric (TG) analysis.

\section{Manufacturing Method and Raw Materials of Lime Mortars in Korea during the Joseon Dynasty (Late 14th to Early 20th Century)}

The folding screen called Taepyeongseongsido, which shows the ideal city sought by the Joseon Dynasty, contains the manufacturing method of the mortar used in this period. One part of this large painting $(1136 \mathrm{~mm} \times 491 \mathrm{~mm})$ is shown in Figure 2, in which traditional building techniques using lime mortars are depicted. On the far left, two people step on the mortars in a wooden frame, leaning against wooden sticks. Considering this manufacture by human feet, it can be inferred that the mortars were mixed using slaked lime rather than quicklime due to the sudden exothermic reaction of quicklime, which also means that the lime was prepared in a state that could be stored and transported. The person sitting next to the wooden frame rolls the manufactured mortars into clumps for delivery. After passing through several people, the mortar is passed to the plasterer, and it is plastered on the wall using tools similar to those used today.

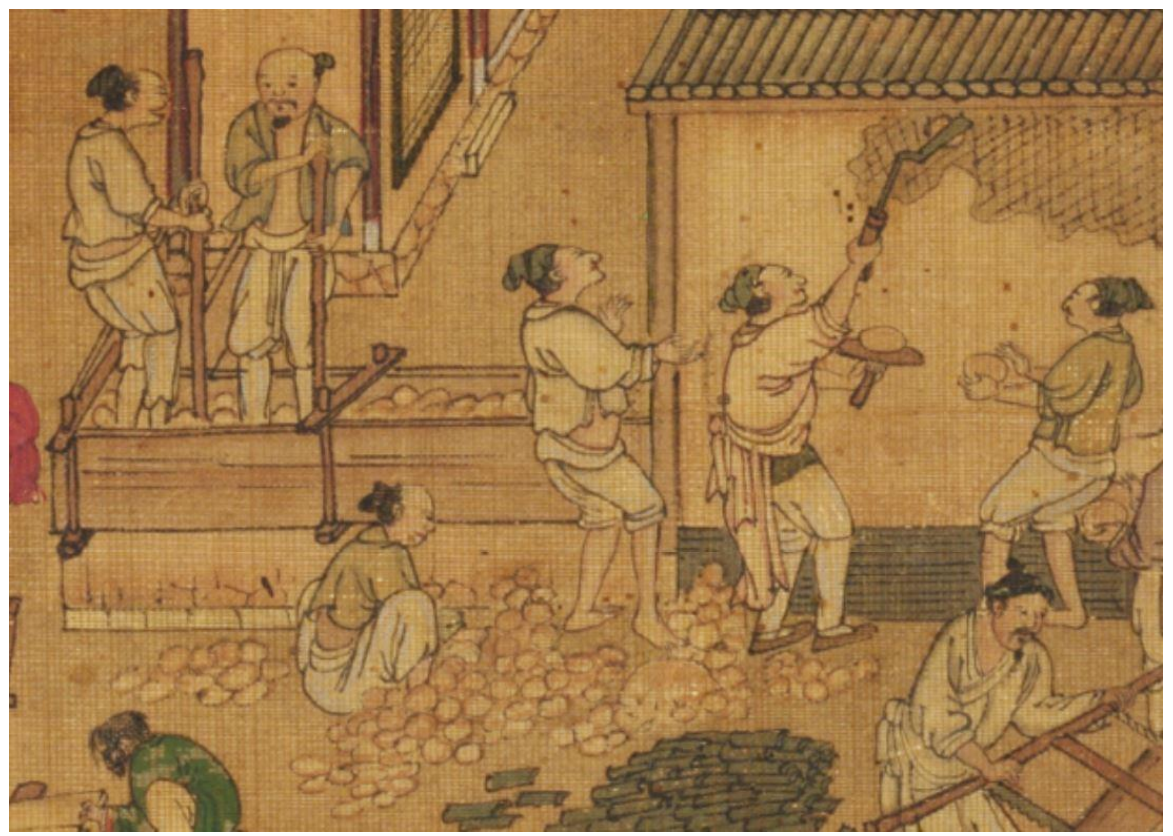

Figure 2. Part of the screen painting of Taepyeongseongsido (The City of Supreme Peace) (National Museum of Korea (https://www.museum.go.kr)).

By reviewing old literature on the selection and firing of limestone, it was found that stones with various colors, such as blue, green, black, yellow, and white, were used as raw materials for lime putty and mortar. The calcining temperature of limestone is difficult to estimate precisely, but people in the past recognized the importance of combustion for the production of better-quality limes. In the annals of the Joseon Dynasty, Munjong daewang sillok (written in 1455 and listed as a UNESCO Memory of the World in 1997), the manufacturing process of lime putty was documented as part of the history of 
1451; that is, blue- or green-black stones buried in the ground were mined and burned in a kiln for three days, and then water was poured over them. In the Sejongshillokchiriji, written in 1454, it was also stated that blue- or green-black stones can be used as the raw material for lime putty. Decades later, in the annals of the Joseon Dynasty, Seongjong daewang sillok (written in 1499 and listed as a UNESCO Memory of the World in 1997), information about the areas with suitable limestone were recorded.

Documentation that lime and lime mortar are important materials for the construction of ramparts can also be found in old literature, e.g., in the annals of the Joseon Dynasty, Sukjong daewang sillok (written in 1728 and listed as a UNESCO Memory of the World in 1997). Moreover, in the book Bukhagui, written in 1778, Jega Bak stated that the strength of stacked stones cannot reach that of stacked bricks, and that 10,000 bricks can be pasted together to make one large stone. He also mentioned the importance of the firing process; limestone must be burned continuously for two and a half days to obtain quicklime, and the thermal power should be kept constant. Thus, in the past, it was empirically recognized that combustion (more specifically, firing temperature and time) is important for obtaining good-quality lime putty.

As mentioned, NHL is produced by calcining low-quality limestone with impurities. Based on a 2010 survey [32], the limestone reserves in South Korea are estimated at about 22.4 billion tons, which can be considered abundant. However, most are buried in Paleozoic strata, not in Mesozoic strata, which is known to contain high-quality limestone without impurities [32]. Therefore, the majority of limestone is low quality. Such limestone can also be identified by visual observation, because impurities such as iron and carbon make the stone darker [33]. This is the reason why high-quality limestone is almost white. In addition, old books written during the Joseon Dynasty distinguished limestone by color, and it was stated that dark-colored limestone is suitable for the manufacture of lime mortars. This implies that limestone containing impurities was utilized in the past to manufacture binders for lime mortars.

\section{Experiment}

\subsection{Preparation of Limestone, Quicklime, and Hydrated Lime}

Based on the literature review summarized in Chapter 2, four limestones with different colors of white, blue-green, ivory, and green-black were prepared. These were mined in a quarry in Chungcheongbuk-do, South Korea, and then crushed to a size of about 150-200 mm. This area is one of the sites where limestone was mined during the Joseon Dynasty, where the largest traditional lime manufacturing facility in Korea was discovered in 2009. As shown in Figure 3a, the four limestones prepared for the experiment were simply named LS_W for white, LS_G for blue-green, LS_I for ivory, and LS_B for green-black limestone.

(a)
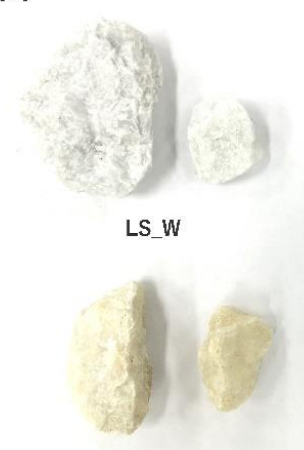

LS_I

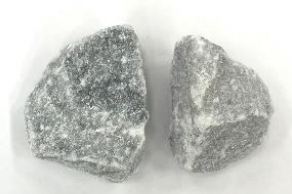

LS_G

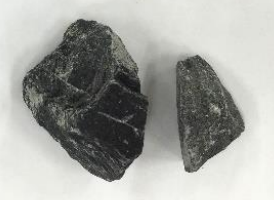

LS_B

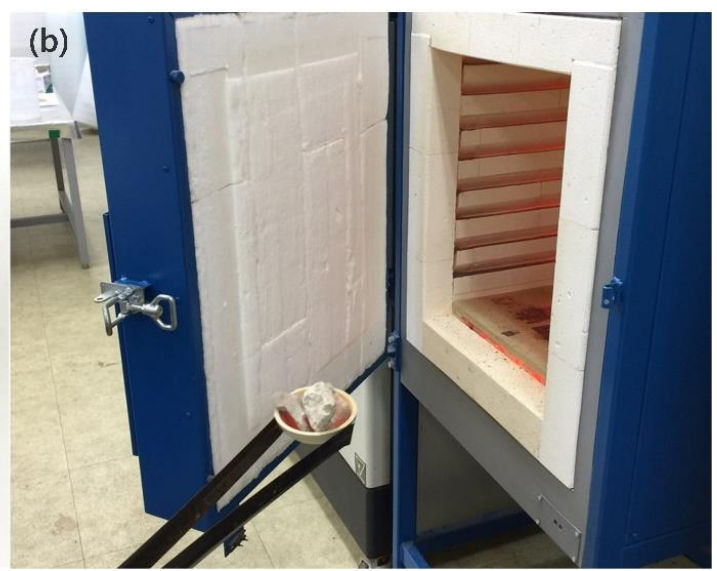

Figure 3. (a) Limestone with four different colors; (b) after calcination in the furnace. 
To produce quicklime, the limestone was calcined for $48 \mathrm{~h}$ at $1200{ }^{\circ} \mathrm{C}$ using a programmable electric furnace with a heating rate of $10^{\circ} \mathrm{C} / \mathrm{min}$. After the calcination, the quicklime was removed from the furnace when the inside temperature had dropped below about $500^{\circ} \mathrm{C}$, as shown in Figure $3 \mathrm{~b}$. The calcined limestone, i.e., quicklime, was ground into powder and immediately afterwards, a chemical analysis was performed to prevent hydration of the calcium oxide $(\mathrm{CaO})$ with moisture in the air. The calcining process of pure limestone and the slaking process of quicklime can be represented chemically by Equations (1) and (2), respectively [1,34]:

$$
\begin{aligned}
& \text { Calcination of limestone }: \mathrm{CaCO}_{3}+\text { Heat } \rightarrow \mathrm{CaO}+\mathrm{CO}_{2} \text {, } \\
& \text { Hydration of quicklime }: \mathrm{CaO}+\mathrm{H}_{2} \mathrm{O} \rightarrow \mathrm{Ca}(\mathrm{OH})_{2}+\text { Heat. }
\end{aligned}
$$

Hydrated or hydraulic lime was produced by slaking $1 \mathrm{~g}$ of quicklime powder with $5 \mathrm{~g}$ of deionized water for seven days. After this, the water contained in the lime slurry was removed by the solvent exchange technique to prepare dry powders to be used as samples for the XRD and TG analyses [35]. According to this technique, the water was removed using a Büchner funnel, an aspirator pump, and a filter paper. The wet powder was placed in a conical tube containing about $50 \mathrm{~mL}$ of isopropanol, and after 10-15 min, the remaining water and solvent were removed from the powder. In the second removal process, diethyl ether was poured into the powder to remove the remaining isopropanol. Finally, the powder remaining on the filter paper was vacuum dried at $40^{\circ} \mathrm{C}$ for $8-10 \mathrm{~min}$.

\subsection{Analysis Methods}

\subsubsection{XRF Analysis for Defining the Limestone's Chemical Composition}

An XRF analysis was performed to investigate the chemical compositions and impurities in limestones of various colors. The main purpose of this analysis was to quantitatively identify the contents of $\mathrm{CaO}$ as a major component, and impurities such as $\mathrm{SiO}_{2}, \mathrm{Al}_{2} \mathrm{O}_{3}, \mathrm{Fe}_{2} \mathrm{O}_{3}$, and $\mathrm{MgO}$. The XRF samples of powdered limestone were prepared using fused beads methods, and they were analyzed using a wavelength dispersive XRF spectrometer (MXF-2400, Shimadzu, Kyoto, Japan). In addition, loss on ignition (LOI) of the powder samples was measured for an accurate estimation of the content.

\subsubsection{XRD Analysis for Characterizing the Crystalline Phase}

To obtain information about the crystalline phase of quicklime and hydrated (or hydraulic) lime, an XRD analysis was performed. The purpose of this analysis was to identify and compare the crystalline phases formed during the calcination of the limestone depending on the chemical composition, which was defined by the XRF analysis. Another aim was to find evidence of hydraulic properties, such as the formation of calcium silicate. Powder samples were flattened in circular grooved holders and placed in an X-ray diffractometer (SmartLab SE, Rigaku, Tokyo, Japan). Then, the analysis was performed using $\mathrm{Cu} \cdot \mathrm{K} \alpha_{1}$ radiation $(\lambda=1.5406 \AA)$ with fixed conditions, such as $40 \mathrm{kV}$ voltage, $40 \mathrm{~mA}$ current, $0.02^{\circ}(2 \Theta)$ step size, and $1^{\circ} / \mathrm{min}$ scanning speed [33]. The $X$-ray patterns were collected within a scanning range of $5-70^{\circ}(2 \Theta)$, and the crystalline phases were detected with software (SmartLab Studio II, Rigaku, Japan), the Inorganic Crystal Structure Database, and the Crystallography Open Database. In addition, Rietveld refinement was performed to obtain quantitative information on the main components, such as $\mathrm{CaO}$ and calcium silicates.

\subsubsection{Isothermal Calorimetry}

As understood from Equation (2), the hydration of quicklime is an exothermic reaction, and it can vary depending on impurities or $\mathrm{CaO}$ content. Isothermal conduction calorimetry was performed to investigate the effects of the chemical composition of quicklime on the hydration heat released during the slaking process. In a $20 \mathrm{~mL}$ glass ampoule, $1 \mathrm{~g}$ of quicklime and $5 \mathrm{~g}$ of deionized water were inserted and mixed gently for about $10 \mathrm{~s}$. Within another $10 \mathrm{~s}$, the ampoule was placed in a calorimeter (TAM Air 
8-channel, TA Instruments, New Castle, DE, USA) that was set at an isothermal state of $20^{\circ} \mathrm{C}$, and the measurement of the exothermic reaction was immediately started [36]. On the third day, the experiment was terminated after confirming that there was no exothermic reaction. The measurement results were expressed as the heat flow and cumulative heat released by $1 \mathrm{~g}$ of quicklime.

\subsubsection{Quantitative Analysis of Hydrated or Hydraulic Lime Using TG analysis}

After the slaking process, a TG analysis was performed to quantitatively compare components of hydrated or hydraulic lime. Among various analysis methods, this technique can easily and accurately quantitatively analyze materials containing certain components, such as $\mathrm{Ca}(\mathrm{OH})_{2}$ and $\mathrm{CaCO}_{3}$; therefore, it is one of the essential methods used for the chemical analysis of lime-based materials [35]. In the case of quicklime, since it had already experienced a high temperature of $1200^{\circ} \mathrm{C}$, no meaningful results could be obtained with this method. However, the contents of the components formed during the slaking process of quicklime could be obtained. During this process, various chemical reactions, such as the hydration of quicklime (Equation (2)), the carbonation of hydrated lime (Equation (3)), and the hydration of dicalcium silicate $\left(\mathrm{Ca}_{2} \mathrm{SiO}_{4}\right.$, simply $\left.\mathrm{C}_{2} \mathrm{~S}\right)$ (Equation (4)), can occur [37]:

$$
\text { Carbonation of hydrated lime : } \mathrm{Ca}(\mathrm{OH})_{2}+\mathrm{CO}_{2} \rightarrow \mathrm{CaCO}_{3}+\mathrm{H}_{2} \mathrm{O} \text {, }
$$

Hydration of dicalcium silicate : $2 \mathrm{Ca}_{2} \mathrm{SiO}_{4}+4 \mathrm{H}_{2} \mathrm{O} \rightarrow 3 \mathrm{CaO} \cdot 2 \mathrm{SiO}_{2} \cdot 3 \mathrm{H}_{2} \mathrm{O}+\mathrm{Ca}(\mathrm{OH})_{2}$.

For the TG analysis, an alumina holder containing $20 \pm 1 \mathrm{mg}$ of the powdered sample was placed in an analyzer (SDT Q600, TA Instruments, New Castle, DE, USA) with an empty reference holder. After confirming the equilibrium of temperature and weight, the weight change of the powder by temperature increase was measured in a nitrogen environment (flow rate: $100 \mathrm{~mL} / \mathrm{min}$ ). The temperature range and heating rate were set at $20-1000^{\circ} \mathrm{C}$ and $10{ }^{\circ} \mathrm{C} / \mathrm{min}$, respectively. After the measurements, sudden weight losses between $350{ }^{\circ} \mathrm{C}$ and $500{ }^{\circ} \mathrm{C}$ and between $550{ }^{\circ} \mathrm{C}$ and $800{ }^{\circ} \mathrm{C}$ were used to calculate the $\mathrm{Ca}(\mathrm{OH})_{2}$ and $\mathrm{CaCO}_{3}$ content, respectively. This was performed using the tangential method. With this method, the areas of the peaks formed in the differential thermogravimetry (DTG) curve were integrated, thereby allowing the $\mathrm{Ca}(\mathrm{OH})_{2}, \mathrm{CaCO}_{3}$, and other contents in the powder samples to be estimated [38].

\section{Experimental Results}

\subsection{Chemical Composition and Cementation Index of Limestone}

The chemical compositions of the limestone with four different colors are shown in Table 1. In terms of $\mathrm{CaO}$ content, white (LS_W) and ivory (LS_I) limestones were markedly high, as much as $55 \%$. Since the weight ratios of the $\mathrm{CaO}$ and $\mathrm{CO}_{2}$ in $\mathrm{CaCO}_{3}$ were 56 and 44, respectively, the two limestones should contain at least $43 \% \mathrm{CO}_{2}$, meaning that almost all of the measured LOI came from the $\mathrm{CO}_{2}$ contained in $\mathrm{CaCO}_{3}$. Therefore, it was concluded that the two limestones are high quality, with purity of $>98 \%$.

Table 1. Chemical composition and cementation index of limestones with different colors (wt. \%).

\begin{tabular}{ccccccccc}
\hline Sample Name & $\mathbf{S i O}_{\mathbf{2}}$ & $\mathbf{A l}_{\mathbf{2}} \mathbf{O}_{\mathbf{3}}$ & $\mathbf{F e}_{\mathbf{2}} \mathbf{O}_{\mathbf{3}}$ & $\mathbf{C a O}$ & $\mathbf{M g O}$ & Others & LOI $^{\mathbf{1}}$ & Cementation Index \\
\hline LS_W & 0.35 & 0.13 & 0.10 & 55.05 & 0.73 & 0.45 & 43.19 & 0.02 \\
LS_G & 2.33 & 0.19 & 0.68 & 48.49 & 5.04 & 0.67 & 42.60 & 0.13 \\
LS_I & 0.71 & 0.16 & 0.15 & 55.18 & 0.38 & 0.22 & 43.20 & 0.04 \\
LS_B & 12.49 & 1.69 & 0.70 & 43.47 & 3.16 & 1.02 & 37.47 & 0.78 \\
\hline \multicolumn{7}{c}{${ }^{1}$ Loss on ignition. }
\end{tabular}


Meanwhile, the CaO content of the blue-green (LS_G) and green-black (LS_B) limestone was $48.5 \%$ and $43.5 \%$, respectively. When applying the ratio of $44 / 54$, the $\mathrm{CO}_{2}$ content was calculated as $38.1 \%$ and $34.1 \%$, respectively. Thus, the $\mathrm{CaCO}_{3}$ content of the two limestones was $86.6 \%$ and $77.6 \%$, respectively, which means that they contain a large number of impurities. Indeed, the contents of $\mathrm{SiO}_{2}$, $\mathrm{Al}_{2} \mathrm{O}_{3}, \mathrm{Fe}_{2} \mathrm{O}_{3}$, and $\mathrm{MgO}$ were significantly higher than those of LS_W and LS_I. In the case of LS_G and LS_B, the measured LOI (shown in Table 1) was 3.3-4.5\% higher than the calculated $\mathrm{CO}_{2}$ content (34.1-38.1\%), which may be due to the decomposed $\mathrm{CO}_{2}$ from the dolomite and organic matter, as well as the $\mathrm{CaCO}_{3}$. As already mentioned, organic matter can contribute to making the stones look gray or black.

One of the most widely used methods for evaluating the hydraulicity of limestone is the cementation index (CI), which was developed by Eckel [39]. This index is calculated with Equation (5), where the content of each component is typically determined by the XRF analysis. According to the CI determined, the lime-based binders could be classified into five categories: pure $(<0.15)$, subhydraulic (0.15-0.30), feebly hydraulic (0.3-0.5), moderately hydraulic (0.5-0.7), and eminently hydraulic (0.7-1.1) [40]. This method is practically useful because only the chemical information of the raw material (i.e., the limestone) is needed to check the degree of hydraulicity of the binders.

$$
\mathrm{CI}=\frac{2.8\left(\mathrm{SiO}_{2}\right)+1.1\left(\mathrm{Al}_{2} \mathrm{O}_{3}\right)+0.7\left(\mathrm{Fe}_{2} \mathrm{O}_{3}\right)}{1.0(\mathrm{CaO})+1.4(\mathrm{MgO})} .
$$

The CI of the limestone used in this study is shown in Table 1. The indexes of LS_W and LS_I range between 0.02 and 0.04 , so they are undoubtedly pure limes. In the case of LS_G, since it contained some impurities, the $\mathrm{CI}$ was determined as 0.13 , which is higher than the other two limestones. However, because the value is slightly lower than 0.15 , the lower limit of the sub-hydraulic lime, LS_G, is also classified as pure lime. On the other hand, LS_B exhibited a remarkably high CI (i.e., 0.78), and thus the binder made of this limestone can be classified as eminently hydraulic lime. More conclusive evidence can be gathered through XRD analysis.

\subsection{XRD Analysis of Quicklime and Evidence of Hydraulicity}

Information on the newly produced compounds during the calcination process can be obtained from Figure 4, which shows the results of the XRD analysis. By comparing the crystalline phases of limestone and quicklime, it was confirmed that the constituents are completely changed at high temperatures. As shown in Figure 4a, since LS_W and LS_I were composed entirely of $\mathrm{CaCO}_{3}$ without impurities, no crystal phases other than $\mathrm{CaO}$ were detected in the quicklimes made of white and ivory limestone (QL_W and QL_I, respectively), as expected, and no notable amorphous humps were seen.

(a)

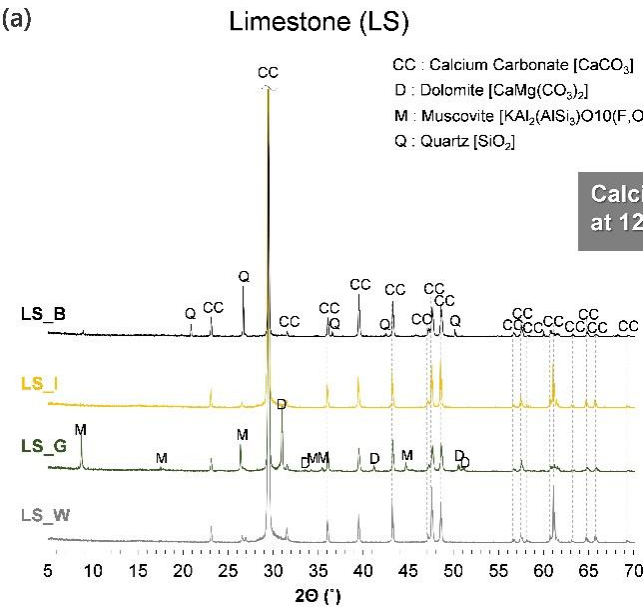

(b)

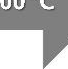
QL_B

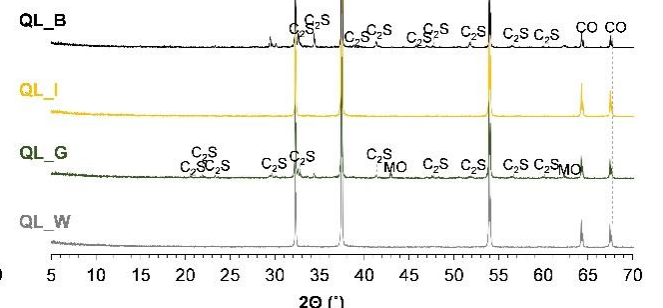

$2 \odot()$

Figure 4. X-ray diffraction (XRD) patterns of (a) limestone and (b) quicklime. 
Meanwhile, LS_G contained dolomite and muscovite, and LS_B contained quartz. In particular, muscovite is one of the main minerals contained in clays [41,42]. In the presence of quartz or clay minerals, the calcination of $\mathrm{CaCO}_{3}$ at a temperature between 800 and $1300{ }^{\circ} \mathrm{C}$ is known to enable the formation of $\mathrm{C}_{2} \mathrm{~S}$ [43,44], and this compound is responsible for the hydraulicity of NHL [45]. Indeed, in the XRD patterns shown in Figure $4 \mathrm{~b}$, the presence of $C_{2} S$ in QL_G and QL_B was clearly identified. The detection of this phase is conclusive evidence of the hydraulic properties of the two limes [46]. Furthermore, based on the quantitative XRD analysis results in Table 2, it was confirmed that the $\mathrm{C}_{2} \mathrm{~S}$ contained in the quicklimes made of blue-green and green-black limestones (QL_G and QL_B, respectively) was $14.6 \%$ and $32.1 \%$, respectively. Therefore, the XRD analysis in this study suggests the possibility of the use of hydraulic lime in Korea during the Joseon Dynasty.

Table 2. Phase composition of quicklime by quantitative XRD analysis (wt. \%).

\begin{tabular}{cccc}
\hline Sample Name & Calcium Oxide & Magnesium Oxide & Dicalcium Silicate \\
\hline QL_W & 100 & - & - \\
QL_G & 80.2 & 5.17 & 14.6 \\
QL_I & 100 & - & - \\
QL_B & 67.9 & - & 32.1 \\
\hline
\end{tabular}

\subsection{Reactivity of Quicklime Containing Dicalcium Silicate}

Figure 5 shows the heat released by $1 \mathrm{~g}$ of quicklime when reacting with water to turn into hydrated lime. In Figure 5a, which shows the heat flow as a function of time, it is seen that the hydration of QL_W and QL_I proceeded very rapidly. They were almost entirely composed of CaO, as mentioned. Most of the reactions occurred for the first $4 \mathrm{~h}$, producing significant calories of up to $250-280 \mathrm{~mW} / \mathrm{g}$. Therefore, the water reactivity of pure quicklime is quite high, especially compared to cement paste, which generally exhibits a maximum heat flow of $<10 \mathrm{~mW} / \mathrm{g}$.

(a)

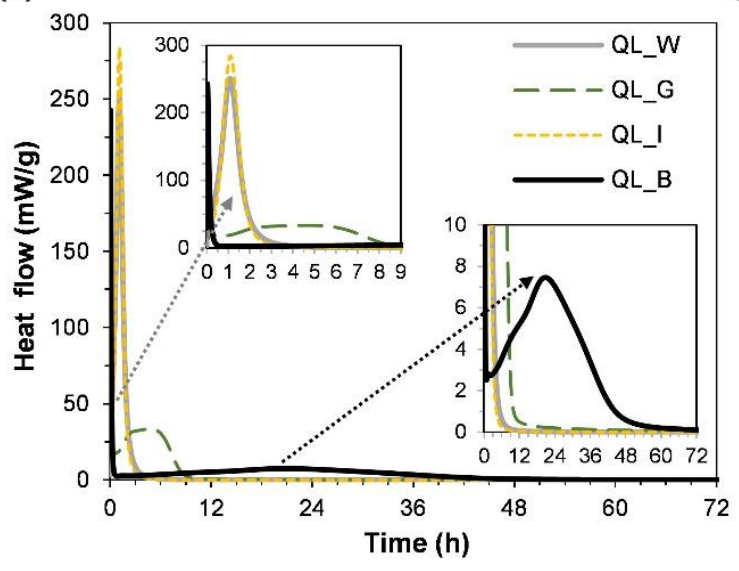

(b)

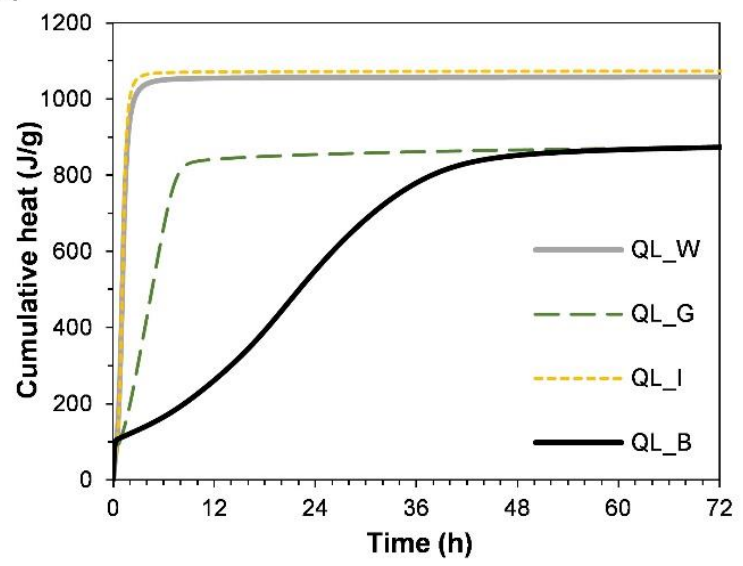

Figure 5. (a) Heat flow and (b) cumulative heat of quicklime during slaking process.

In the case of QL_G containing $80 \% \mathrm{CaO}$, the maximum heat flow reached $140 \mathrm{~mW} / \mathrm{g}$ within a few minutes after mixing with water, but soon dropped to $17 \mathrm{~mW} / \mathrm{g}$; after that, the exothermic reaction continued for about $8 \mathrm{~h}$, while the heat flow increased up to $33 \mathrm{~mW} / \mathrm{g}$. On the other hand, in the case of QP_B, with just $68 \% \mathrm{CaO}$, it exhibited a strong exotherm of $250 \mathrm{~mW} / \mathrm{g}$ for the first few minutes after contact with water, but thereafter it fell sharply to $3 \mathrm{~mW} / \mathrm{g}$ within $30 \mathrm{~min}$. Again, the heat flow gradually increased, while forming a peak with a height of $7.5 \mathrm{~mW} / \mathrm{g}$ at about $24 \mathrm{~h}$. This is similar to the acceleration period found in the hydration heat evolution of ordinary Portland cement [21,47]. After the top of the peak was formed, the deceleration period was also formed, in which the heat flow gradually decreased between 24 and $48 \mathrm{~h}$. 
Based on the cumulative heat shown in Figure $5 b$, the hydration of quicklime can be further explained. The exotherm of QL_W and QL_I converged at about $4 \mathrm{~h}$, showing 1000-1050 J/g calories. On the other hand, the convergence was further delayed to $8 \mathrm{~h}$ and $48 \mathrm{~h}$ in QL_G and QL_B, respectively. This result is a good example of the characteristics of quicklime made of low-quality limestone, known as slow slaking [39]. The cumulative heat of the two quicklimes was $850-1050 \mathrm{~J} / \mathrm{g}$, which is about 200 $\mathrm{J} / \mathrm{g}$ lower than the quicklimes made of high-quality limestone. This can be explained by the low content of exothermic material $(\mathrm{CaO})$ due to impurities. In addition, the presence of $\mathrm{C}_{2} \mathrm{~S}$ may have contributed to their slow exothermic reaction. The crystallization of $\mathrm{CaO}$ through the reaction with water is known to be possible not only around its particles but also within its pores [48], but the compounds formed at a high temperature (i.e., $\mathrm{C}_{2} \mathrm{~S}$ ) can reduce the reactivity of $\mathrm{CaO}$ by blocking the pores [49]. Because it contains more of such compounds, the slaking speed of QL_B should be much slower than that of QL_G. Although $\mathrm{C}_{2} \mathrm{~S}$ also releases heat during the hydration reaction, the amount is negligible compared to that released by quicklime hydration.

\section{4. $X R D$ and TG Analyses of Hydrated and Hydraulic Limes}

The XRD patterns of the slaked quicklime, i.e., the hydrated or hydraulic limes, are presented in Figure 6. Since $\mathrm{CaO}$ was transformed to $\mathrm{Ca}(\mathrm{OH})_{2}$, it was not detected. In addition, $\mathrm{C}_{2} \mathrm{~S}$ was still present in HL_G and HL_B because of its slow hydration (where HL means hydrated or hydraulic lime). The induction period of $\mathrm{C}_{2} \mathrm{~S}$, called belite in cement chemistry, is known to be several days or weeks [47].

\section{Hydrated or hydraulic lime (HL)}

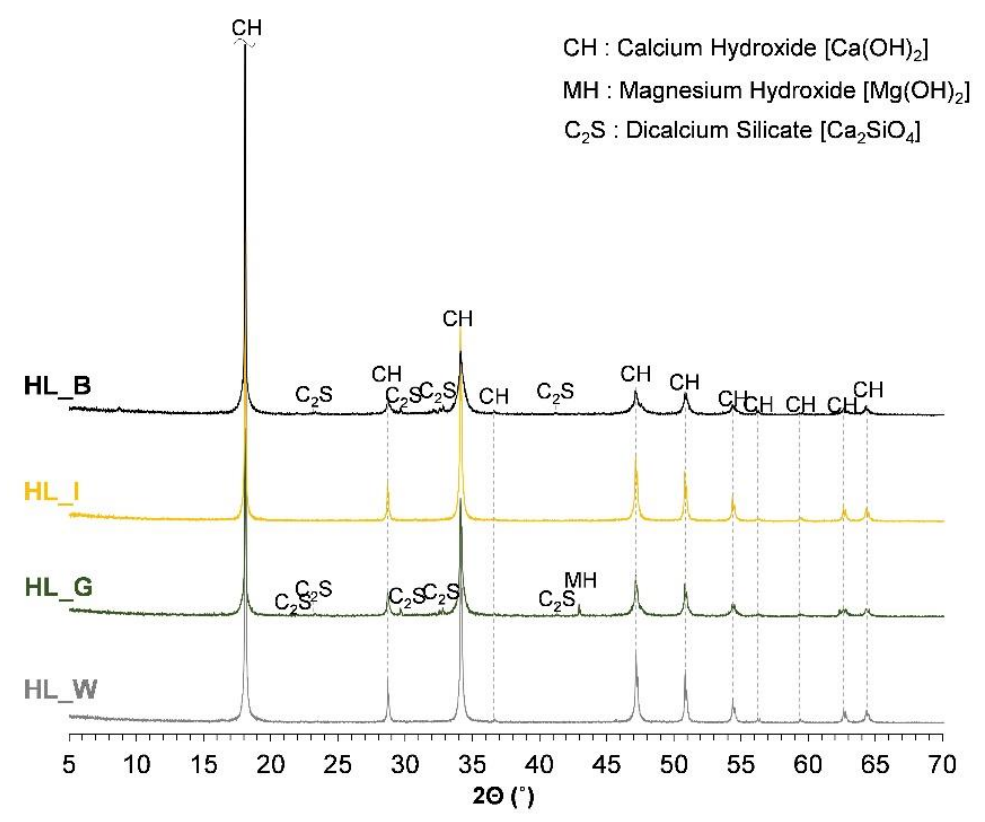

Figure 6. XRD patterns of hydrated or hydraulic lime.

The contents of the main components of the lime measured by the TG analysis are seen in Figure 7. Figure 7a shows the weight loss (red lines) and the DTG curves (blue lines) as a function of temperature, whereas Figure $7 \mathrm{~b}$ shows the weight ratio of $\mathrm{Ca}(\mathrm{OH})_{2}, \mathrm{CaCO}_{3}$, and the other components calculated using the tangential method. 
(a)

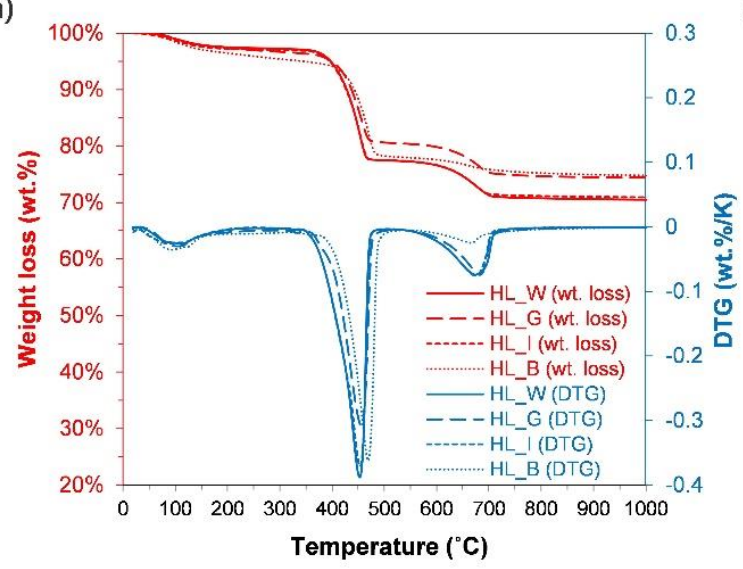

(b)

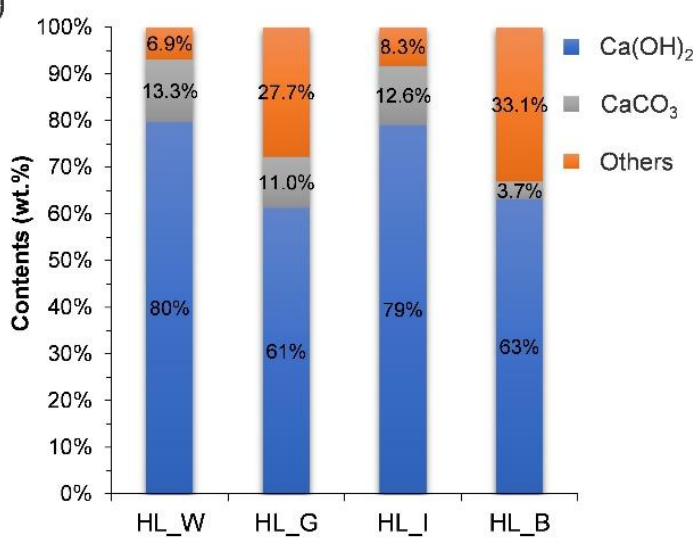

Figure 7. Results of the thermogravimetric (TG) analysis: (a) weight loss (red lines) and differential thermogravimetry (DTG) curves (blue lines); (b) contents of constituents.

HL_W and HL_I contained 79-80\% $\mathrm{Ca}(\mathrm{OH})_{2}$ and $12.6-13.3 \% \mathrm{CaCO}_{3}$. On the other hand, the $\mathrm{Ca}(\mathrm{OH})_{2}$ and $\mathrm{CaCO}_{3}$ contents of $\mathrm{HL} \_\mathrm{G}$ were $61 \%$ and $11 \%$, respectively, which were lower than those of the two limes, especially in the $\mathrm{Ca}(\mathrm{OH})_{2}$ content. In the case of $\mathrm{HL} \_\mathrm{B}$, the $\mathrm{Ca}(\mathrm{OH})_{2}$ and $\mathrm{CaCO}_{3}$ content was measured as $63 \%$ and $3.7 \%$, respectively. The $\mathrm{Ca}(\mathrm{OH})_{2}$ content of $\mathrm{HL} \_\mathrm{B}$ was $2 \%$ higher than that of HL_G, as shown in Figure $7 \mathrm{~b}$. This is because a high amount of $\mathrm{Ca}(\mathrm{OH})_{2}$ can result in more precipitation of $\mathrm{CaCO}_{3}$ under a given amount of $\mathrm{CO}_{2}$. The carbonation reaction would have occurred because the $\mathrm{CO}_{2}$ in the atmosphere dissolved in the deionized water during the slaking process.

Another notable result is that, unlike TG analysis, no $\mathrm{CaCO}_{3}$ was detected in the XRD pattern (Figure 6), even though the same samples were used. The reason for this difference between the two methods may be that the $\mathrm{CaCO}_{3}$ particles precipitated were too small to be detected or the particles were composed of amorphous phases [50]. Finally, when compared to the lime without impurities (HL_W and HL_I), HL_G and HL_B were significantly higher in content other than $\mathrm{Ca}(\mathrm{OH})_{2}$ and $\mathrm{CaCO}_{3}$, which again confirms the inclusion of components such as $\mathrm{C}_{2} \mathrm{~S}$, which cannot be identified by TG analysis.

\section{Discussion and Conclusions}

The sustainable preservation of architectural heritage is particularly important because it is not just for use and residence, it is also an asset of humankind to be passed down intact to the next generation. In reality, this heritage is deteriorated by various environmental factors and even people. In a situation like that in South Korea, where knowledge about traditional building materials and techniques has been almost forgotten due to rapid industrialization and social change, the preservation of historical buildings based on unfounded customs and a lack of scientific knowledge can seriously deteriorate the historical buildings' structural safety and durability. Since much of Korea's architectural heritage has been recently listed as UNESCO World Heritage Sites, a proper understanding of the raw materials and materials for repairing them has become more important than ever before.

Furthermore, it is also important to understand the concept of preventive conservation. Especially, this study emphasized the importance of selecting suitable repair materials, since it is a strategy for the preventive conservation of historic masonry structures. The repair and restoration of heritage masonry structures which depends only on two extremely different materials, Portland cement and non-hydraulic lime, has created many problems. However, the use of suitable materials, such as NHL, can significantly reduce the dependence on cement, which in turn contributes to preventive and sustainable conservation of architectural heritage.

NHL has been widely used in historic buildings all over the world, and its suitability has been demonstrated in many studies and in practice. Important information, such as the characteristics of 
the raw materials, manufacturing processes, chemical composition, and mechanical properties, is well established in the standard, such as UNI EN 459-1 [51], so that reliable information and experience can be shared. In Korea, it is necessary to focus on research on the material properties as well as the improvement and application of NHL-based materials, but there has been a lack of justification and understanding for its use. In an effort to overcome this, historical and experimental evidence was collected in this study, while emphasizing the importance of the hydraulic properties of lime-based materials. Consequently, three important pieces of evidence for the possibility of manufacturing hydraulic lime were found:

1. Literature written in the 15th century stated that dark (including blue- or green-black) stones were burned to make lime putty or mortar;

2. Low-quality limestone containing impurities was commonly mined in Korea;

3. The CI of green-black limestone mined in Chungcheongbuk-do, which was one of the mining sites during the Joseon Dynasty, was significantly high, as much as 0.78 . On the basis of this value, the production of eminently hydraulic lime can be expected, and indeed the manufactured lime contained a significantly high amount of $\mathrm{C}_{2} \mathrm{~S}$.

Based on the above facts only, it is still early to assert the use of hydraulic lime in Korea. However, this possibility can be suggested due to the current study being in early stages. This suggestion also raises the need for continuing research to find additional evidence. Apart from this, the calorimeter experiment performed in this study quantitatively showed the decreases in the rate of hydration and the total calories released during lime slaking, because of the impurities contained. The link between this finding and chemical composition analysis can help to clearly understand the characteristics of hydration or exothermic reaction of the limes with or without hydraulic properties.

In early 1900, Eckel, who systematically investigated limestone in the United States, noted that limestone containing more than $5 \%$ impurities generally has dark colors, and it has hydraulic properties when burned [39]. Although the calcining temperature of limestone during the Joseon Dynasty is difficult to know exactly, it is likely that hydraulic lime was used during this period, considering a wide range of temperatures $\left(800-1300^{\circ} \mathrm{C}\right)$ that enabled the formation of $\mathrm{C}_{2} \mathrm{~S}$ [43]. Through the findings of this study, the importance of hydraulic lime can be emphasized, and a good justification for carrying out relevant studies is provided. This research can help to select suitable materials and methods for repair and restoration, and as a result will contribute to the sustainable preservation and preventive conservation of Korea's architectural heritage.

Author Contributions: S.-H.K. and Y.-H.K. conducted experiments, analyzed the test results and wrote the manuscript. S.-O.L. collected raw materials, surveyed and interpreted old literatures. S.-G.H. advised on the interpretation of the results and manuscript revision.

Funding: This research was supported by Basic Science Research Program through the National Research Foundation of Korea (NRF) funded by the Ministry of Education (NRF-2018R1A2A3074938).

Acknowledgments: The Institute of Engineering Research in Seoul National University provided research facilities for this work.

Conflicts of Interest: The authors declare no conflict of interest.

\section{References}

1. Carran, D.; Hughes, J.; Leslie, A.; Kennedy, C. A short history of the use of lime as a building material beyond Europe and North America. Int. J. Archit. Herit. 2012, 6, 117-146. [CrossRef]

2. Veiga, R. Air lime mortars: What else do we need to know to apply them in conservation and rehabilitation interventions? A review. Constr. Build. Mater. 2017, 157, 132-140. [CrossRef]

3. Shao, M.; Li, L.; Chen, W.; Liu, J. Investigation and modification of two kinds of Chinese traditional lime in cultural building relics. J. Cult. Herit. 2019, 36, 118-127. [CrossRef] 
4. Sabbioni, C.; Zappia, G.; Riontino, C.; Blanco-Varela, M.T.; Aguilera, J.; Puertas, F.; Balen, K.V.; Toumbakari, E.E. Atmospheric deterioration of ancient and modern hydraulic mortars. Atmos. Environ. 2001, 35, 539-548. [CrossRef]

5. Sabbioni, C.; Bonazza, A.; Zappia, G. Damage on hydraulic mortars: The Venice Arsenal. J. Cult. Herit. 2002, 3, 83-88. [CrossRef]

6. Kang, S.-H.; Kwon, Y.-H.; Moon, J. Quantitative analysis of $\mathrm{CO}_{2}$ uptake and mechanical properties of air lime-based materials. Energies 2019, 12, 2903. [CrossRef]

7. Grilo, J.; Faria, P.; Veiga, R.; Santos Silva, A.; Silva, V.; Velosa, A. New natural hydraulic lime mortars-Physical and microstructural properties in different curing conditions. Constr. Build. Mater. 2014, 54, 378-384. [CrossRef]

8. Dai, S.B. Building limes for cultural heritage conservation in China. Herit. Sci. 2013, 1, 1-9. [CrossRef]

9. Hansen, E.F.; Rodríguez-Navarro, C.; Balen, K. Lime putties and mortars. Stud. Conserv. 2008, 53, 9-23. [CrossRef]

10. Ritchie, T. Study of efflorescence produced on ceramic wicks by masonry mortars. J. Am. Ceram. Soc. 1955, 38, 362-366. [CrossRef]

11. Del Hoyo-Meléndez, J.M.; Mecklenburg, M.F.; Doménech-Carbó, M.T. An evaluation of daylight distribution as an initial preventive conservation measure at two Smithsonian Institution Museums, Washington, DC, USA. J. Cult. Herit. 2011, 12, 54-64. [CrossRef]

12. Bichlmair, S.; Raffler, S.; Kilian, R. The Temperierung heating systems as a retrofitting tool for the preventive conservation of historic museums buildings and exhibits. Energy Build. 2015, 95, 80-85. [CrossRef]

13. Balocco, C.; Petrone, G.; Maggi, O.; Pasquariello, G.; Albertini, R.; Pasquarella, C. Indoor microclimatic study for Cultural Heritage protection and preventive conservation in the Palatina Library. J. Cult. Herit. 2016, 22, 956-967. [CrossRef]

14. Sahin, C.D.; Coşkun, T.; Arsan, Z.D.; Gökçen Akkurt, G. Investigation of indoor microclimate of historic libraries for preventive conservation of manuscripts. Case Study: Tire Necip Paşa Library, İzmir-Turkey. Sustain. Cities Soc. 2017, 30, 66-78. [CrossRef]

15. Balocco, C.; Volante, G. A method for sustainable lighting, preventive conservation, energy design and technology-lighting a historical church converted into a university library. Sustainability 2019, 11, 3145. [CrossRef]

16. Lucchi, E. Review of preventive conservation in museum buildings. J. Cult. Herit. 2018, 29, $180-193$. [CrossRef]

17. Caneva, G.; Bartoli, F.; Fontani, M.; Mazzeschi, D.; Visca, P. Changes in biodeterioration patterns of mural paintings: Multi-temporal mapping for a preventive conservation strategy in the Crypt of the Original Sin (Matera, Italy). J. Cult. Herit. 2019. [CrossRef]

18. Prados-Peña, M.B.; Gutiérrez-Carrillo, M.L.; Del Barrio-García, S. The development of loyalty to earthen defensive heritage as a key factor in sustainable preventive conservation. Sustainability 2019, 11, 3516.

19. Chung, K.-Y.; Lee, S.-O.; Yang, H.-J. Factor analysis of deterioration in Namhansanseong yeojang. J. Archit. Hist. 2016, 25, 10. (In Korean) [CrossRef]

20. Chung, K.-Y.; Cha, H.-S. Investigation and removal method of efflorescence phenomenon of traditional bricks-focusing on the efflorescence of Hwaseong Fortress in Suwon. J. Archit. Hist. 2013, 22, 59-66. (In Korean) [CrossRef]

21. Kang, S.-H.; Hong, S.-G.; Moon, J. Importance of drying to control internal curing effects on field casting ultra-high performance concrete. Cem. Concr. Res. 2018, 108, 20-30. [CrossRef]

22. Forster Alan, M. Building conservation philosophy for masonry repair: Part 2-"principles". Struct. Surv. 2010, 28, 165-188. [CrossRef]

23. Kang, S.-H.; Kwon, Y.-H.; Hong, S.-G.; Chun, S.; Moon, J. Hydrated lime activation on byproducts for eco-friendly production of structural mortars. J. Clean Prod. 2019, 231, 1389-1398. [CrossRef]

24. Lawrence, R.M.H. A Study of Carbonation in Non-Hydraulic Lime Mortars. Ph.D. Thesis, University of Bath, Bath, UK, 2006. 
25. Groot, C.; van Hees, R.; Papayianni, I. Durability Aspects Related to Repointing of Historic Mortars with Lime Based Mortars. In Proceedings of the International Conference on Sustainable Materials, Systems and Structures (SMSS2019): Durability, Monitoring and Repair of Structures, Rovinj, Croatia, 20-22 March 2019; Baričević, A., Jelčić Rukavina, M., Damjanović, D., Guadagnini, M., Eds.; RILEM Publications S.A.R.L.: Rovinj, Croatia, 2019; pp. 644-651.

26. Barr, S.; McCarter, W.J.; Suryanto, B. Bond-strength performance of hydraulic lime and natural cement mortared sandstone masonry. Constr. Build. Mater. 2015, 84, 128-135. [CrossRef]

27. Lanas, J.; Arandigoyen, M.; Alvarez, J.I.; Bernal, J.L.P.; Bello, M.A. Mechanical behavior of masonry repair mortars: Aerial and hydraulic lime-based mixtures. In Proceedings of the 10th International Congress on Deterioration and Conservation of Stone, Stockholm, Sweden, 27 June-2 July 2004; Löfvendahl, D.K.R., Ed.; ICOMOS Sweden: Stockholm, Sweden, 2004; p. 8.

28. Válek, J.; Veiga, R. Characterisation of mechanical properties of historic mortars-testing of irregular samples. WIT Trans. Built Environ. 2005, 83, 10.

29. Jonaitis, B.; Antonovič, V.; Šneideris, A.; Boris, R.; Zavalis, R. Analysis of physical and mechanical properties of the mortar in the historic retaining wall of the Gediminas Castle Hill (Vilnius, Lithuania). Materials 2018, 12, 8. [CrossRef] [PubMed]

30. De Nardi, C.; Bullo, S.; Cecchi, A.; Ferrara, L. Self-healing capacity of advanced lime mortars. Advances in Mater. Process. Technol. 2016, 2, 349-360. [CrossRef]

31. Forster Alan, M. Building conservation philosophy for masonry repair: Part 1-“ethics". Struct. Surv. 2010, 28, 91-107. [CrossRef]

32. Korea Limestone Industry Cooperation. Korea Limestone Industry Guide Book: Dynamic Lime Industry; Korea Limestone Industry Cooperation: Seoul, Korea, 2013; p. 32. (In Korean)

33. Kang, S.-H.; Hong, S.-G.; Moon, J. The use of rice husk ash as reactive filler in ultra-high performance concrete. Cem. Concr. Res. 2019, 115, 389-400. [CrossRef]

34. Dotsika, E.; Kyropoulou, D.; Christaras, V.; Diamantopoulos, G. $\delta 13 \mathrm{C}$ and $\delta 18 \mathrm{O}$ stable isotope analysis applied to detect technological variations and weathering processes of ancient lime and hydraulic mortars. Geosciences 2018, 8, 339. [CrossRef]

35. Scrivener, K.; Snellings, R.; Lothenbach, B. A Practical Guide to Microstructural Analysis of Cementitious Materials; CRC Press: Boca Raton, FL, USA, 2016.

36. Kang, S.-H.; Jeong, Y.; Kim, M.O.; Moon, J. Pozzolanic reaction on alkali-activated Class F fly ash for ambient condition curable structural materials. Constr. Build. Mater. 2019, 218, 235-244. [CrossRef]

37. Mehta, P.K.; Monteiro, P.J. Concrete-Microstructure, Properties and Materials; McGeaw-Hill: New York, NY, USA, 2006.

38. Kang, S.-H.; Lee, J.-H.; Hong, S.-G.; Moon, J. Microstructural investigation of heat-treated ultra-high performance concrete for optimum production. Materials 2017, 10, 1106. [CrossRef] [PubMed]

39. Eckel, E.C. Cements, Limes and Plasters: Their Materials, Manufacture, and Properties; John Wiley \& Sons: New York, NY, USA, 1905; p. 712.

40. TC 203-RHM. RILEM TC 203-RHM: Repair mortars for historic masonry. Mater. Struct. 2012, 45, 1287-1294. [CrossRef]

41. Freitas Dutra, L.; Freitas, M.E.; Grillet, A.-C.; Mendes, N.; Woloszyn, M. Microstructural characterization of porous clay-based ceramic composites. Materials 2019, 12, 946. [CrossRef] [PubMed]

42. Schelz, J.P. The detection of quartz in clay minerals by differential thermal analysis. Thermochim. Acta 1976, 15, 17-28. [CrossRef]

43. Taylor, H.F. Cement Chemistry; Thomas Telford: New York, NY, USA, 1997.

44. Válek, J.; van Halem, E.; Viani, A.; Pérez-Estébanez, M.; Ševčík, R.; Šašek, P. Determination of optimal burning temperature ranges for production of natural hydraulic limes. Constr. Build. Mater. 2014, 66, 771-780. [CrossRef]

45. Lanas, J.; Pérez Bernal, J.L.; Bello, M.A.; Alvarez Galindo, J.I. Mechanical properties of natural hydraulic lime-based mortars. Cem. Concr. Res. 2004, 34, 2191-2201. [CrossRef]

46. Gulotta, D.; Toniolo, L.; Binda, L.; Tedeschi, C.; van Hees, R.; Nijland, T.G. Investigation of Commercial Ready-Mixed Mortars for Architectural Heritage. In Proceedings of the 11th International Conference on Structural Repairs and Maintainance of Heritage Architecture, STREMAH 2009, Tallinn, Estonia, 22-24 July 2009; TNO Bouw en Ondergrond: Tallinn, Estonia, 2009; pp. 231-241. 
47. Hewlett, P. Lea's Chemistry of Cement and Concrete, 4th ed.; Butterworth-Heinemann: Oxford, UK, 2010.

48. Ramachandran, V.S.; Sereda, P.J.; Feldman, R.F. Mechanism of hydration of calcium oxide. Nature 1964, 201, 288-289. [CrossRef]

49. Elert, K.; Rodriguez-Navarro, C.; Pardo, E.S.; Hansen, E.; Cazalla, O. Lime Mortars for the Conservation of Historic Buildings. Stud. Conserv. 2002, 47, 62-75. [CrossRef]

50. Rodriguez-Navarro, C.; Elert, K.; Ševčík, R. Amorphous and crystalline calcium carbonate phases during carbonation of nanolimes: Implications in heritage conservation. CrystEngComm 2016, 18, 6594-6607. [CrossRef]

51. British Standards Institution (BSI). Building lime. Definitions, Specifications and Conformity Criteria; BS EN 459-1: 2015; BSI Standards Publication: London, UK, 2015.

(C) 2019 by the authors. Licensee MDPI, Basel, Switzerland. This article is an open access article distributed under the terms and conditions of the Creative Commons Attribution (CC BY) license (http://creativecommons.org/licenses/by/4.0/). 